DOI: http://dx.doi.org/10.33846/hn50303

http://heanoti.com/index.php/hn

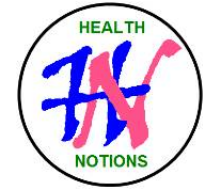

RESEARCH ARTICLE

URL of this article: http://heanoti.com/index.php/hn/article/view/hn50303

\title{
The Effect of Quality of Service on Patient Satisfaction and its Implications on The Interest of Patients to Use Health Services Back at Jember Regency Health Center
}

\author{
Ahmad Afifuddin Sholeh ${ }^{1(\mathrm{CA})}$, Isa Ma'rufi' ${ }^{2}$, Zarah Puspitaningtyas ${ }^{3}$ \\ 1(CA) Post Graduate School of Publich Health Science, Universitas Jember, Indonesia; \\ emailnyaafif27@gmail.com (Corresponding Author) \\ ${ }^{2}$ Department of Enviromental Health, Faculty of Publich Health, Universitas Jember, Indonesia \\ ${ }^{3}$ Department of Social Science and Political Science, Universitas Jember, Indonesia
}

\begin{abstract}
Health center is a health care facility that organizes public health efforts and first-rate individual health efforts, with more priority on promotional and preventive efforts to achieve the highest level of public health in the working area. Quality of service is something related to the fulfillment of customer expectations / needs, where the service is said to be quality when it can provide products and services (services) in accordance with the needs and expectations of customers. This research was an analytical research with a cross sectional approach. This research was conducted at Health Center in Jember Regency. The population in this study was 474,972 patients with a sample size of 400 patients, selected using accidental sampling techniques. Data were collected using documentation and interviews with questionnaires, then analyzed using AMOS software to examine how much influence the two independent variables on the dependent variables, could be seen from the coefficient of determination or estimate. The results showed that most of the respondents were adult, female, had marital status, had the last level of education finished junior high school, and had a type of job not working or other. Most respondents had an average income of about 2-3 million rupiah per month, have mileage to health facilities was less than 10 kilometers or categorized closely, have travel time to health facilities was less than 10 minutes or categorized briefly, and had participated in or participated in health insurance programs. The quality of service in the health center according to most respondents was considered quite good.
\end{abstract}

Keywords: quality of service; patient interest; health services

\section{Background}

INTRODUCTION

Health development is an integral and most important part of national development, the aim of holding health development is to increase awareness, willingness and ability to live a healthy life for everyone in order to achieve an optimal degree of public health. The success of health development plays an important role in improving the quality and competitiveness of Indonesia's human resources. Regulation of the Minister of Health Number 75 of 2014 concerning "Community Health Centers", is the legal basis for administering Health Center. The Health Center, which is the Technical Implementation Unit of the District / City Health Office, is a health service facility that organizes public health efforts and first-level individual health efforts, by prioritizing promotive and preventive efforts to achieve the highest public health degree in its working area. The vision of health development organized by the Health Center is the achievement of a Healthy District towards the realization of a Healthy Indonesia. Healthy sub-districts are a picture of the future sub-district community that they want to achieve through health development, namely people who live in the environment and with behavior healthy, has the ability to reach quality health services fairly and equitably, and has the highest degree of health. Healthy subdistrict indicators are: healthy environment, healthy behavior, quality health service coverage, and the health status of the sub-district population.

Health Center accreditation is a recognition given by independent institutions of accreditation providers after meeting accreditation standards. The main objective of Health Center accreditation is to foster the improvement of the quality of service and patient safety through continuous improvement of the quality management system, program implementation system, and the application of risk management, and not just an assessment to obtain an accreditation certificate. The approach used in accreditation Health Center is the safety s. 
and rights of patients and families, while paying attention to the rights of officers. This principle is upheld as an effort to improve the quality of service and patient safety.

According to Dabholkar et al, service quality can be measured using 5 dimensions, namely: Physical Aspects, Reliability, Personal Interaction, Problem Solving, and Policy ${ }^{(1)}$. Quality is basically related to good service, namely the attitude or the way employees serve customers or society satisfactorily. According to Kotler, et al. patient satisfaction is the feeling of pleasure and disappointment of the patient as a result of the comparison between perceived performance and expectations ${ }^{(2)}$. Patients will be satisfied if the services they get are at least the same or exceed patient expectations. Meanwhile, dissatisfaction will arise if the outcome does not meet the patient's expectations. Service quality and satisfaction are two things that cannot be separated, because with satisfaction, related parties can correct each other to what extent the services provided are getting better or worse $\mathrm{e}^{(3)}$. In accordance with Maya research, it was concluded that service quality affects patient satisfaction at dr. Soegiri Lamongan $^{(4)}$. Similar research was also conducted by Djeinne, it was found that the quality of service was related to patient satisfaction in the disease polyclinic in the GMIM Pancaran Kasih Manado Hospital ${ }^{(5)}$.

Based on a preliminary study that has been conducted at the Jember District Health Office, data on the accreditation status of Health Center until 2019, the Health Center accreditation assessment in Jember starting from the lowest includes Basic Accreditation, Intermediate Accreditation and data for IKM (Community Satisfaction Index) assessments starting from Low Criteria, Enough and Good. 50 Health Center that have been accredited until 2019 or all public health centers in Jember Regency have been accredited with different accreditation results. The Kaliwates Health Center which has been fully accredited has received low criteria for the IKM (Community Satisfaction Index) assessment, which means that most patients are still not satisfied with Kaliwates health center services. On the other hand, the Paleran Health Center even though it is still accredited as Intermediate, has received an IKM (Community Satisfaction Index) assessment with good criteria which means it gives satisfaction to its patients ${ }^{(6)}$.

Several other Health Center with major accreditation have also not been able to give satisfaction to their patients, namely Health Center Gumukmas, Health Center Ledokombo and Health Center Kencong, namely the criteria for the assessment of the IKM (Community Satisfaction Index) are still low. In contrast to the community health care pukesmas whose accreditation status is still at the intermediate level but are only able to get an IKM (Community Satisfaction Index) assessment with good criteria, namely Jenggawah Health Center, Jelbuk Health Center, Jelbuk Health Center, Sumberjambe Health Center, Balung Health Center, Silo I Health Center, mumbulsari Health Center, Health Center Semboro, Health Center Karangduren and Health Center Gladakpakem. This description can be concluded that patient satisfaction is not always directly proportional to the status of the Health Center accreditation score ${ }^{(6)}$. Based on the above description of the background issues important researchers to examine more deeply about how to influence the quality of service to client satisfaction and its implications on the interests of patients to use health care services at the health center back at Jember Regency Health Center.

\section{Purpose}

The purpose of this study is to analyze the influence of service quality on patient satisfaction and its implications for the patient's interest in using health services again at the Jember District Health Center. Identifying predisposing factors for patients at the Jember District Health Center. Identifying patient enabling factors at the Jember District Health Center. Identifying the quality of service at the Jember District Health Center. Identifying patient satisfaction at the Jember District Health Center. Identifying patient interest in using health services again at the Jember District Health Center. Analyzing the effect of service quality on patient satisfaction at the Jember District Health Center. Analyzing the effect of patient satisfaction on patient interest in using health services again at the Jember District Health Center. Analyzing the effect of service quality on patient interest in using health services again at the Jember District Health Center.

\section{METHODS}

This research was conducted in October-December 2020 at Health Center in Jember Regency. Analytical research with cross sectional approach is research to study the dynamics of correlation between risk factors and effects, by way of approach, observation, or data collection at once (point time approach). This study used non probability sampling technique. Calculation of sample size using quota sampling technique. The sample size was 400 respondents, 50 health centers in Jember regency spread across 31 subdistricts which means in one Health Center taken as many as 8 respondents. The sampling techniques in this study was accidental sampling.

The independent variables in this study were predisposition factors, possible factors, and service quality. The dependent variables in this study were patient satisfaction and patient interest in using health care services again. Data collection techniques through documentation and interview studies. The test of research instruments included a test of validity and reliability of research questionnaires conducted in four health centers in Bondowoso district the number of samples of 40 patients Health Center with details of 10 patients Kotakulon Health Center, Wonosari Health Center, Prajekan Health Center, and Nangkaan Health Center located in Bondowoso Regency. 
Data processing techniques using editing, scoring, tabulating. The technique of presenting research data was carried out through three kinds, namely presentation in the form of textular, presentation in the form of graphs, and presentation in the form of tables. Data analysis techniques in this study were descriptive analysis and multivariate analysis.

\section{RESULTS}

Structural Equation Modeling (SEM) has the ability to present a comprehensive model together with its ability to confirm the dimensions or factors of a concept through empirical indicators and its ability to measure influence between factors that theoretically exist. Therefore SEM is usually viewed as a combination of factor analysis and regression analysis, and of course it can be applied separately only in factor analysis or in regression analysis. Some of the conventions that apply in SEM are as follows ${ }^{(9)}$ :

a. Measurable variable (measured variable): This variable is called also observed variables, indicator variables or multivest variables, depicted in the form of a rectangle or square. Measurable variables are variables whose data must be sought through field research, for example through survey instruments.

b. Factor: is avariable, which is formed through indicators observed in the real world, because it is avariable, it is called a latent variable, and another name is constructs or unobserved variables. Factors in SEM are described in terms of a circle, oval or ellipse.

c. Relationship between variables: the relationship between these variables is expressed in the form of a line. Therefore, if there is no line it means that there is no direct relationship to the hypothesized. SEM modeling can be carried out using two-step modeling approach, namely first developing a measurement model and the second is a structural model.

SEM has guidelines for the smallest to largest sampling size levels in the estimation technique in AMOS, namely:

a. Maximum Likelihood Estimation (ML)

b. Generalized Least Square Estimation (GLS)

c. Unweighted Least Square Estimation (ULS)

d. Scale Free Least Square Estimation (SLS)

e. Asympotically Distribution - Free Estimation (ADF)

Ferdinand in Haris reveals that the data that has been collected will be processed further using theapplication program Structural Equation Modeling (SEM)which is operated through the IBM® SPSS AMOS version 23.0 program $^{(9)}$. Structural equation modeling, SEM is a set of statistical techniques that allows testing of a complex series of relationships, simultaneously. Several reasons for using the SEM program as an analytical tool are that SEM is suitable for:

a. Confirming the unidimensionalization of various indicators for a construct / concept / factor

b. Test the suitability / appropriateness of a model based on the empirical data studied.

c. Test the suitability of the model as well as the causal relationship between the factors built / observed in the research model.

Based on the research results, the effect of service quality on patient satisfaction and its implications for the patient's interest in using health services again at the Jember district health center using the SPSS AMOS 23 statistical test tool is as follows:

Table 1. Result (default model)

\begin{tabular}{ll}
\hline Computation of degrees of freedom (default model) & \\
\hline Number of distinct sample moments & 190 \\
Number of distinct parameters to be estimated & 41 \\
Degrees of freedom $(190-41)$ & 149 \\
Result (Default model) & Minimum was achieved \\
Chi-square & 976,860 \\
Degrees of freedom & 149 \\
Probability level & 0,000 \\
\hline
\end{tabular}

Table 1 shows the results which shows the of output the analysis multivariate in the table (default model) word minimum was achieved and degrees of freedom with a positive value of 149, so the processes in the model can be done. This is in accordance with Santoso because $\mathrm{df}$ is positive and sentence "Minimum was achieved" at the software output test, the testing process has been carried out, with probability level $=0.000$ can use the type of identification Just identified ${ }^{(10)}$. In SEM terminology it is called saturated. The following is a picture of the results of graphic analysis after performing calculations and the data can be accepted for analysis using SPSS AMOS $23^{(10)}$ :

However, the Chi-square calculated value $=976.860$ shows that the greater value is greater than the chi square table $=178.485$ which shows that the model cannot be said to be fit ${ }^{(10)}$. This can occur because there are 
too many variables and indicators and / or the research sample is too small, the suggestion for the number of test samples using software the good AMOS 23 multivariate testin the SEM method is between 150 data to 400 data $^{(10)}$.

Kusnendi, states that thecoefficient Cronbach Alpha is one of the widely used instrument reliability tests. Another method is Confirmatory Factor Analysis (CFA) ${ }^{(11)}$. CFA according to Joreskog and Sorborn is used to test unidimensional, validity and reliability of construct measurement models that cannot be measured directly ${ }^{(12)}$. The measurement model or also known as the descriptive model ${ }^{(13)}$, measurement theory ${ }^{(14)}$, or the confirmatory factor model shows the operationalization of research variables or constructs into measurable indicators formulated in equations and or specific path diagrams ${ }^{(15)}$.

The purpose of the CFA is to confirm or test a model, that is, a measurement model whose formulation comes from theory. So, CFA can be said to have two focus studies, namely whether the indicators are conceptualized unidimensional, precise, and consistent and what indicators are dominant to form the construct under study. In CFA, the measurement model refers to the RMT. RMT itself is a measurement model developed based on classical theory. RMT is of the view that based on the understanding or understanding of constructs derived from theory, it can be identified. Measurable indicators as a reflection or manifest of the construct.

The refractory indicator model assumes that the variation in the construct measurement score is a function of the true score plus the error. This model is often referred to as the principal factor model where the covariance measurement of indicators is influenced by latent constructs, or reflects variations of latent constructs ${ }^{(16)}$. The opposite of the refractory indicator model is the formative model. (an explanation of the formative indicator model will be explained separately).

Simply put, the RMT model is characterized ${ }^{(16)}$ :

a. Latent construct changes will affect changes in indicators (Bollen and Lennox, 1991)

b. The direction of the causality relationship from construct to indicator (arrows from construct to indicator)

c. Between measures of indicators are expected to be correlated (measures must have internal consistency reliability)

d. Removing indicators from the measurement model will not change the meaning or meaning of the construct.

e. Calculating the measurement error (error) at the indicator level

f. The score scale does not describe the construct.

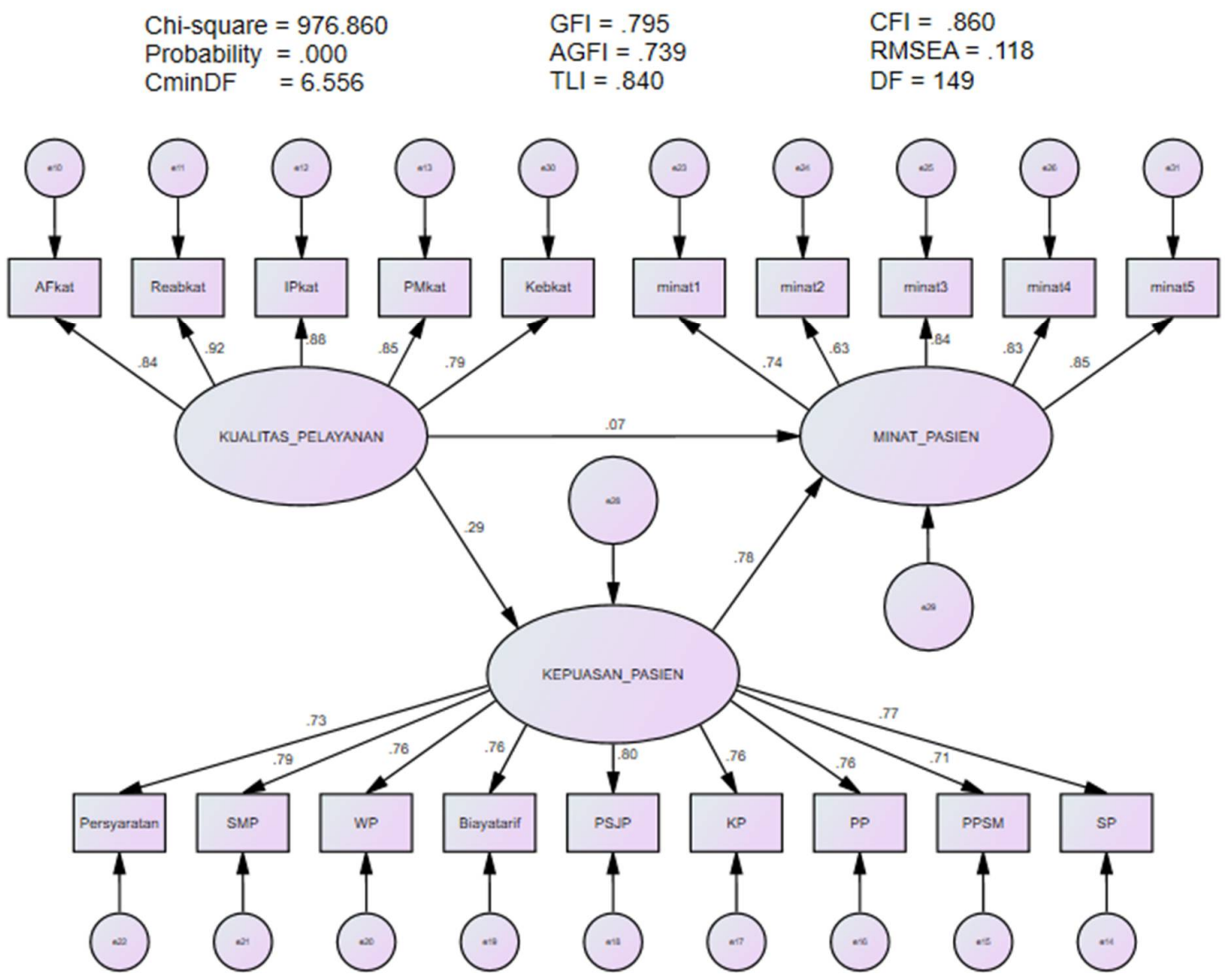

Figure 1. Analysis using SPSS AMOS 23 
The CFA process refers to the RMT model, so the first step taken is to examine the theory of the construct to be measured. From the theory, theoretical concepts and constitutive definitions (theoretical definitions) are obtained about the constructs to be measured. Furthermore, dimensions or measurable indicators can be identified as a reflection or manifest of the following constructs:

Figure 1. Service Quality CFA shows that there are five indicators (manifest variables) that make up QUALITY OF SERVICE (latent variables), namely AFkat with a value of 0, 84, Reabkat with a value of 0.92 , GPA with a value of 0.88 , PMkat with a value of 0.85 and Kebkat with a value of 0.79 . The five indicators show avalue product moment $>0.6$ so that the six indicators are valid and reliable. Then it can be said that AFkat, Reabkat, IPkat, PMkat and Kebkat contribute simultaneously to form QUALITY OF SERVICE. The biggest contribution to forming QUALITY OF SERVICE is Reabkat with avalue product moment of 0.92.

Figure 1 (CFA Patient Satisfaction) shows that there are nine indicators (manifest variable) forming PATIENT SATISFACTION (Latent variable), namely Requirements with a value of 0.73 , SMP with a value of 0.79 , WP with a value of 0.76 , Biayatarif with a value of 0.76 , PSJP with a value of 0.80 , KP with a value of 0.76 , PP with a value of 0.76 , PPSM with a value of 0.71 , and SP with a value of 0.77 . The nine indicators show avalue product moment $>0.6$ so that the nine indicators are valid and reliable. Then the requirements, SMP, WP, Biayatarif, PSJP, KP, PP, PPSM, and SP can be said that they contribute simultaneously to form SATISFACTION_PASIEN. The biggest contribution to forming SATISFACTION_PASIENT is PSJP with avalue product moment of 0.80 .

Figure 1 (Patient Interest CFA) shows that there are five indicators (manifest variables) that make INTER_PATIENT (latent variables) namely interest 1 with a value of 0.74 , interest 2 with a value of 0.63 , interest 3 with a value of 0.84 , interest 4 with a value of 0.83 and Interests 5 with a value of 0.85 . The five indicators show avalue product moment $>0.6$ so that the four indicators are valid and reliable. Then it can be said that interest 1 , interest2, interest 3 , interest 4 and interest 5 contribute simultaneously to form INTEREST_PATIENT. The biggest contribution to forming MINAT_PASIEN is interest5 with avalue product moment of 0.85 .

The next result is a descriptive description to know the significance value $(\mathrm{P})$ bivariate of regression of weight (estimate) of each variable and indicator, is as follows:

Table 2. Estimates (group number 1 - default model)

\begin{tabular}{ccccccc}
\hline & \multicolumn{2}{c}{ Regression Weights: (Group number 1 - Default model) } & & \\
\hline & \multicolumn{7}{c}{} & \multicolumn{1}{c}{ Estimate } & S.E. & C.R. & $P$ \\
\hline PATIENT INTEREST & $<---$ & PATIENT SATISFACTION & 0.260 & 0.048 & 5.394 & $* * *$ \\
\hline PATIENT INTEREST & $<---$ & QUALITY OF SERVICE & 0.570 & 0.045 & 12.783 & $* * *$ \\
\hline AFkat & $<---$ & QUALITY OF SERVICE & 0.044 & 0.025 & 1.727 & 0.084 \\
\hline Reabkat & $<---$ & QUALITY OF SERVICE & 1.000 & & & \\
\hline IPkat & $<---$ & QUALITY OF SERVICE & 1.074 & 0.044 & 24.246 & $* * *$ \\
\hline PMkat & $<---$ & QUALITY OF SERVICE & 1.047 & 0.046 & 22.547 & $* * *$ \\
\hline Kebkat & $<---$ & QUALITY OF SERVICE & 1.074 & 0.050 & 21.366 & $* * *$ \\
\hline SP & $<---$ & PATIENT SATISFACTION & 1.000 & & & \\
\hline PPSM & $<---$ & PATIENT SATISFACTION & 0.978 & 0.066 & 14.899 & $* * *$ \\
\hline PP & $<---$ & PATIENT SATISFACTION & 1.092 & 0.068 & 15.976 & $* * *$ \\
\hline KP & $<---$ & PATIENT SATISFACTION & 1.087 & 0.068 & 16.032 & $* * *$ \\
\hline PSJP & $<---$ & PATIENT SATISFACTION & 1.184 & 0.069 & 17.156 & $* * *$ \\
\hline Tariff Fee & $<---$ & PATIENT SATISFACTION & 1.109 & 0.069 & 16.033 & $* * *$ \\
\hline WP & $<---$ & PATIENT SATISFACTION & 1.093 & 0.068 & 16.160 & $* * *$ \\
\hline SMP & $<---$ & PATIENT SATISFACTION & 1.140 & 0.068 & 16.852 & $* * *$ \\
\hline Requirements & $<---$ & PATIENT SATISFACTION & 1.026 & 0.067 & 15.311 & $* * *$ \\
\hline Interest 1 & $<---$ & PATIENT INTEREST & 1.000 & & & \\
\hline Interest 2 & $<---$ & PATIENT INTEREST & 0.848 & 0.068 & 12.515 & $* * *$ \\
\hline Interest 3 & $<---$ & PATIENT INTEREST & 1.143 & 0.068 & 16.914 & $* * *$ \\
\hline Interest 4 & $<---$ & PATIENT INTEREST & 1.155 & 0.069 & 16.807 & $* * *$ \\
\hline Interest 5 & $<---$ & PATIENT INTEREST & 0.895 & 0.048 & 18.823 & $* * *$ \\
\hline PATIENT INTEREST & $<---$ & PATIENT SATISFACTION & 1.169 & 0.069 & 17.069 & $* * *$ \\
\hline
\end{tabular}

Table 2 shows the results validity of data can be seen from the calculation of spss statistical tool AMOS 23 shows the value of $\mathrm{P}$ shows a sign $* * *$ which means the influence shows a level of significance below 0.01 . Analysis of this research has a confidence level of 0.05 which means the value of $\mathrm{P}$ when showing results below 0.05 still shows a significant value, but if the value of $\mathrm{P}$ above 0.05 means insignificant. In this study, the variable quality of service to patient interest showed a $\mathrm{P}$ value of 0.084 so that it can be said that the quality of service to the patient's interest has no significant effect. However, Multivariate service quality variables have an indirect effect on patient interest variables through satisfaction variables.

The next result is a descriptive description to know the Standardized regression of weight (estimate) value of each variable. 
Tabel 3. Standardized estimates (group number 1 - default model)

\begin{tabular}{|c|c|c|c|}
\hline \multicolumn{4}{|c|}{ Standardized regression weights: (group number 1 - default model) } \\
\hline & & & Estimate \\
\hline PATIENT SATISFACTION & $<---$ & QUALITY OF SERVICE & 0.290 \\
\hline PATIENT INTEREST & $<---$ & PATIENT SATISFACTION & 0.785 \\
\hline PATIENT INTEREST & $<---$ & QUALITY OF SERVICE & 0.067 \\
\hline AFkat & $<---$ & QUALITY OF SERVICE & 0.836 \\
\hline Reabkat & $<---$ & QUALITY OF SERVICE & 0.922 \\
\hline IPkat & $<---$ & QUALITY OF SERVICE & 0.883 \\
\hline PMkat & $<---$ & QUALITY OF SERVICE & 0.854 \\
\hline Kebkat & $<---$ & QUALITY OF SERVICE & 0.788 \\
\hline SP & $<---$ & PATIENT SATISFACTION & 0.770 \\
\hline PPSM & $<---$ & PATIENT SATISFACTION & 0.713 \\
\hline PP & $<---$ & PATIENT SATISFACTION & 0.756 \\
\hline KP & $<---$ & PATIENT SATISFACTION & 0.759 \\
\hline PSJP & $<---$ & PATIENT SATISFACTION & 0.802 \\
\hline Tariff Fee & $<---$ & PATIENT SATISFACTION & 0.759 \\
\hline WP & $<---$ & PATIENT SATISFACTION & 0.764 \\
\hline SMP & $<---$ & PATIENT SATISFACTION & 0.791 \\
\hline Requirements & $<---$ & PATIENT SATISFACTION & 0.730 \\
\hline Interest 1 & $<---$ & PATIENT INTEREST & 0.744 \\
\hline Interest 2 & $<---$ & PATIENT INTEREST & 0.635 \\
\hline Interest 3 & $<--$ & PATIENT INTEREST & 0.840 \\
\hline Interest 4 & $<---$ & PATIENT INTEREST & 0.835 \\
\hline Interest 5 & $<---$ & PATIENT INTEREST & 0.847 \\
\hline
\end{tabular}

Based on the table 3, the value of the effect of service quality on patient satisfaction at the Jember District Health Center is 0.290 . This means that if the quality of service is getting better, patient satisfaction will increase by 0.290 times. The effect of patient satisfaction on patient interest in using health services again at the Jember District Health Center is 0.785 . That is, if patient satisfaction increases, the patient's interest in using health services will again increase by 0.785 times. The influence quality of service on patient interest in using health services again at the Jember District Health Center is 0.067. This means that if the quality of service is getting better, the patient's interest in using health services will increase again by 0.067 times

\section{DISCUSSION}

\section{The Effect of Quality of Service on Patient Satisfaction in Jember Regency Health Center}

The quality of service in Jember Regency Health Center is considered quite good by most respondents. Benchmarks used to evaluate nationally the quality of health services by using assessment standards that have been determined in the accreditation of health services and for leadership governance. The most dominant indicator of service quality shaping the quality of service is reliability. Respondents stated that the flow of services ranging from registration to drug redemption is quite easy. Respondents also said that the doctor's service hours were appropriate according to the schedule. In addition, respondents assessed that patient care was quick and appropriate. Other indicators such as personal interactions were also rated fairly well by respondents.

Most of the respondents considered that patient satisfaction at the Health Center Kabupaten Jember was satisfactory. The indicator of patient satisfaction that most dominantly forms patient satisfaction is a product specification for the type of service. Respondents stated that the examination, treatment and care services were carried out quickly and precisely. Respondents also stated that officers are responsive and able to serve patient complaints well. Health Center not only prioritizes quality assurance but also pays attention to customer assurance. Officers not only provide services according to procedures, but officers also take a personal approach to patients and their families. So it is natural that the level of patient satisfaction at the Jember District Health Center is quite high. Mahda found that service quality has a direct and positive effect on patient satisfaction ${ }^{(17)}$. This shows that the better the quality of service, the more patient satisfaction increases. Boadi et al with their research in Ghana, argued that the quality of services from health care agencies has an effect on patient satisfaction $^{(18)}$. Priyono et al also stated that service quality has an effect on patient satisfaction ${ }^{(19)}$.

As found in Kaliwates Health Center, Gumukmas Health Center, Ledokombo Health Center, and Kencong Health Center, the quality of service reliability indicators get low grades and followed by low patient satisfaction rates or can be said to be dissatisfied. This is because the reliability indicator is the most dominant indicator in shaping the quality of service with a product moment value of 0.92 . Reliability indicator consists of several items, among others, ease of service flow from registration to drug redemption, suitability of doctor's service hours with a predetermined schedule and speed and accuracy in patient care 
Based on the results of this study and previous studies, it can be assumed that service quality does have an effect on patient satisfaction. This means that in order to achieve a high level of patient satisfaction, the health services provided by the health center must be of high quality. Service is called quality if each service quality indicator which includes physical aspects, reliability, personal interaction, problem solving, and policy is also of quality.

\section{The Effect of Patient Satisfaction on Patient Interest to Use Health Services Back In Jember Regency Health Center}

Patient satisfaction in Jember Regency Health Center was considered satisfactory by most respondents. Respondents stated that the service procedure was clearly conveyed by the officer. Respondents also stated that the service procedure is quite easy and simple. Respondents assessed that the inpatient rooms and toilets in the Health Center were quite comfortable and clean. The state of the tools used is also in a clean state. Respondents also stated that there are comfortable and clean sinks and toilets in the health center. Respondents stated that the officers provide a good service and full of responsibility. In addition, respondents also assessed that the officers were polite and friendly. Respondents stated that officers wear complete attributes including uniforms, shoes, and IDs. Some of these things can be the basis why the level of patient satisfaction in jember regency health center is quite high.

Most of the respondents considered the patients' interest in using health services again at the Health Center in Jember Regency to be quite high. Most of the respondents stated that they would return to using health services at the Health Center. Respondents also stated that they would recommend health services at the Health Center to others. This shows that the enthusiasm or interest of patients to reuse services at Health Center is quite high. The patient's interest is of course based on their satisfaction or satisfaction with the health services at the Health Center. Patients who are satisfied will reuse or reuse health services at the Jember District Health Center. Sukiswo found in his research that patient satisfaction was related to interest in revisiting health centers ${ }^{(20)}$. Hamdan explains that patient satisfaction is related to patient loyalty ${ }^{(21)}$. Positive patient behavior will then build trust which can directly affect patient loyalty. Patient satisfaction is one of the things in developing patient loyalty. The patient's positive behavioral intention is the intention to return to the health care agency. Positive patient loyalty such as an example of Word of Mouth a goodwill make return visits and this shows patient satisfaction.

Based on the results of this study and previous studies it can be assumed that patient satisfaction has an effect on patient interest in using health services again at the health center. This means that to be able to achieve a high level of patient interest in using health services again at the health center, the patient must first feel satisfied. Satisfied patients are based on quality service. So that the higher the level of patient satisfaction, the patient's interest in using health services again at the health center is getting higher and in the end the value or number of visits will increase.

\section{The Effect of Quality of Service on Patient Interest to Use Health Services Back In Jember Regency Health Center}

The quality of service in Jember Regency Health Center is considered quite good by most respondents. Respondents stated that the doctor asked for patient complaints and was willing to provide the right solution. Respondents assessed that paramedics (nurses and midwives) are sensitive in assisting complaints and patient needs. Respondents also stated that security guards and parking attendants are willing to help patients' needs. Respondents stated that the physical building of Health Center is clean and beautiful. In addition, respondents said that medical equipment in the health center is complete and modern. The patient's family lounge is also considered safe and comfortable. Respondents said that patient visiting hours were orderly and scheduled. Respondents assessed that service rates are relatively affordable. Respondents also assessed that the comfort of the parking space is quite good.

The results of this study indicate that the quality of service affects the patient's interest in using health services again at the Jember District Health Center, but the effect is small. Good service quality will have an impact on increasing patient satisfaction and satisfied patients will reuse health services at the Health Center. Batubara et al stated that patient satisfaction has a positive and significant effect on patient satisfaction and patient satisfaction has a positive and significant effect on Word of Mouth. Word of Mouth (WOM) is a personal or non-personal statement conveyed by someone other than the service provider (Health Center) to the customer (potential patient) ${ }^{(22)}$. Customers (prospective patients) usually accept WOM quickly because those who convey it are those they can trust, such as friends and family. In addition, WOM is also quickly accepted as a reference because service customers usually find it difficult to evaluate services that they have not purchased or have not experienced themselves.

Meanwhile, Elizar et al stated that patient trust significantly mediates the effect of service quality on patient loyalty. By maintaining patient trust through the provision of services based on accreditation standards of health care agencies and continuous evaluation, patient loyalty will increase marked by patient return visits even though there are other health care agencies that offer similar services, even customers will recommend the health service agency to others. Based on the results of this study and previous studies, it can be assumed that the better the quality of service, the more patient interest in reusing health services at the Health Center will also increase ${ }^{(23)}$.

\section{CONCLUSION}

Service quality affects patient satisfaction at the Jember District Health Center. Patient satisfaction affects the patient's interest in using health services again at the Jember District Health Center. the quality of service does 
not have a direct effect on patient's interest but the quality of service affected on the patient's interest to use health services again through patient satisfaction at the Jember District Health Center.

Jember Regency Health Center in general and Kaliwates Health Center, Gumukmas Health Center, Ledokombo Health Center, and Kencong Health Center in particular should be able to maintain and improve the quality of service, especially on reliability indicators consisting of several items, among others, ease of service flow, suitability of doctor's service hours, and speed and accuracy in patient care must be improved so that patient satisfaction can also be improved considering the reliability indicators in the four Health Center are still relatively poor. In addition, indicators of physical aspects and problem solving also need to be improved because there are still patients in some health centers who judge that both components are still bad. Health Center Jember regency should be able to increase patient satisfaction, especially in the component of handling complaints, suggestions, and inputs because the component is considered still unsatisfactory by most respondents. Health Center should be able to provide a separate unit managed by a guard who specializes in handling complaints and suggestions in each room / unit. Then the health center must also follow up and validate the advice and input given by the patient. Further research is expected to dig deeper based on the problems in this research and can answer other factors that have not been studied in this research instrument.

\section{REFERENCES}

1. Dabholkar, et al. A Measure of Service Quality for Retail Stores: Scale Development and Validation. Journal of Academy Marketing Science. 1996;24(1):3-16.

2. Kotler, et al. Marketing Management 13 ed. New Jersey: Pearson Practice Hall. Inc.; 2012.

3. Kurniati. Satisfaction of Class III Lontara Inpatients to Health Services in Hospitals. Wahidin Sudirohusodo Makassar. Undergraduate Thesis. Makassar: UNHAS; 2013.

4. Maya D. The Effect of Quality of Service on Outpatient Satisfaction of Dr. Soegiri Lamongan Hospital. Thesis. Malang: Universitas Brawijaya; 2017.

5. Djeinne T. The Relationship between Service Quality and Patient Satisfaction in Internal Disease Polyclinics of GMIM Pancaran Kasih Manado Hospital. Thesis. Manado: Universitas Sam Ratulangi; 2018.

6. Dinkes Jember. Report on Accountability of Jember District Health Office 2019. Jember: Dinkes Jember; 2019.

7. Yusuf AM. Research Methods: Quantitative, Qualitative and Joint Research. Jakarta: Kencana; 2014.

8. Hartati N. Statistics For Research Data Analysis. Bandung: Pustaka Setia; 2017.

9. Mahda AA. The Effect of Quality of Service on Bed Occupancy Rate through Patient Satisfaction. Thesis. Jember: Universitas Jember; 2020.

10. Harris I. Analysis of Technology Acceptance Model (TAM) on E-Learning Acceptance Rate Among Students. Batam Universal University; 2017.

11. Santoso S. AMOS 22 untuk Structural Equation Modeling. Jakarta: PT. Elex Media Komputindo; 2015.

12. Kusnendi. Models of Structural Equations. One and Multi-Group Sample with LISREL. Bandung: Alfabeta; 2008.

13. Joreskog KG, Sorbom D. Lisrel 8: Structural Equation Modeling With The SIMPLIS Command Language. Chicago: SSI Inc.; 1993.

14. Ferdinand. Management Research Methods: Research Guidelines for Thesis, Thesis, and Desertation of Management Science. Semarang: Diponegoro University Publishing Board; 2002.

15. Hair JFJr., Anderson RE, Tatham RL, Black WC. Multivariate Data Analysis Sixth Edition. New Jersey: Prentice Hall International Inc.; 2006.

16. Long JS. Confirmatory Factor Analysis: A Preface to LISREL. California: Sage Publications; 1983.

17. Ghozali. SEM Alternative Method with Partial Least Square. Edisi 2. Semarang: BP-UNDIP; 2008.

18. Boadi EB, Wenxin W, Bentum-Micah G, Asare IKJ, Bosompem LS. Impact of Service Quality on Customer Satisfaction in Ghana Hospitals: A PLS-SEM Approach. Canadian Journal Of Applied Science And Technology Vol. 7 (3): 503-511.

19. Priyono B, Indasah, Koesnadi. Analysis Quality of Services on and Satisfaction Loyalty Patients Sumberglagah Hospital Mojokerto. Journal for Quality in Public Health Journal. 2020;3(2):232-238.

20. Sukiswo SS. Relationship of Patient Satisfaction With Interest in Re-Visit in Health Center Sangkalah District Susoh West Aceh Regency. Journal of Faculty of Public Health, Teuku Umar University. 2018;5(8):52-61.

21. Hamdan NS, Musa H, Selamat AS, Rashid N. Investigating Factors of Service Quality Influencing Patient Satisfaction towards Patient Loyalty. International Journal of Advanced Science and Technology. 2019;28(16):452-459.

22. Batubara AW, Ginting W, Lubis AN. The Effect of Quality of Service On Satisfaction And Word Of Mouth Students Diploma III Study Program Tax Administration Fisip USU. Jurnal Manajemen \& Bisnis. 2014;14(2):191-202.

23. Elizar C, Indrawati R, Syah TYR. Service Quality, Customer Satisfaction, Customer Trust, and Customer Loyalty in Service of Paediatric Polyclinic Over Private H Hospital of East Jakarta, Indonesia. Journal of Multidisciplinary Academic Science, Engineering and Social Science Series. 2020;4(2):105-111. 